\title{
Aircraft Lasta Take-Off and Landing Performance
}

\author{
Miodrag Milenković-Babić ${ }^{1)}$ \\ Vuk Antonić ${ }^{1)}$ \\ Mišo Prodic ${ }^{1)}$ \\ Vanja Stefanović-Gobeljić ${ }^{1)}$ \\ Rade Radonjić ${ }^{1)}$ \\ Stevan Jovičić ${ }^{2)}$ \\ Novak Nedić ${ }^{3)}$
}

\begin{abstract}
Analysis of the take-off and landing distance of a single tractor propelled aircraft LASTA is presented in this paper. The purpose of the analysis is to enable certification of the LASTA aircraft according to civil regulations CS-23. The paper presents the approximated method for calculating take-off and landing distance and compares it with the flight test results. Good agreement between these two results is obtained
\end{abstract}

Key words: take-off performance, landing performance, single-engine aircraft, flight tests.

\section{Introduction}

$\mathrm{A}_{2}$ IRCRAFT are designed to satisfy regulations criteria [12]. For civil aircraft, the main handling requirement is that the aircraft can be maneuvered safely and accurately by pilot. The required manipulations must not require forces beyond pilot's strength, and control movements must not be fatiguing. Controls of the aircraft commands should be easily learned in the first place, and must at least conform to conventional common sense of deflection and forces.

Compatibility with regulation requirements is confirmed by flight tests. During this program various configurations are tested to include aborted take-off, crosswind operations, wet/ice runway operation, landing in various configurations, etc. All these tests must be accomplished at various gross weights, airport altitudes, temperatures, humidity and other, according to the regulations [1-2]. More than other tests, takeoff and landings are affected by factors which cannot be accurately measured nor properly compensated. Ground effects on aerodynamic characteristics, transient state process, different pilot technique, air density and many other effects are present during these maneuvers. Major obstacles to the development and validation of reliable design estimation methods for take-off and landing distance are firstly the complexity of the problem, and secondly the sensitivity to the different pilot techniques. Estimations of aircraft capabilities are possible within rather broad limits, relying on a statistical average of numerous tests to minimize errors.

Basic equations for take-off and landing distance [3] are well-known for a long time. General methodology and computer model that offers rapid study of these performances for preliminary design evaluation are given in [4-5]. These nonlinear equations can only be integrated numerically using computers. This paper presents an approximated method for estimation of take-off and landing distances based on information given in [5]. The information presented in [5], gives three methods for estimation of take-off distance. The presented method is specifically adapted to the typical pistonengine configuration as is LASTA aircraft given in Fig.1, whereas its geometry is given in Table 1 .

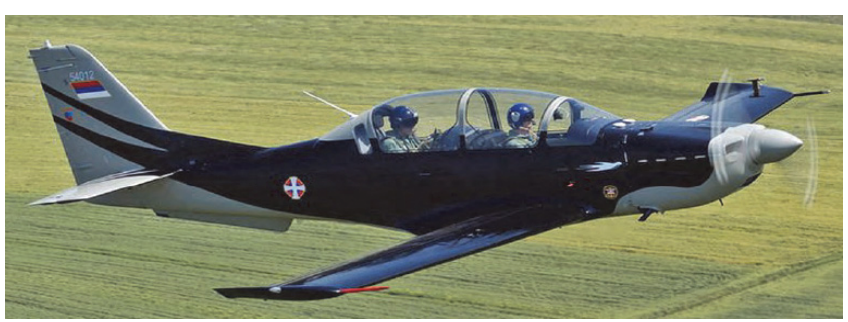

Figure 1. LASTA aircraft [6]

Table 1. Aircraft geometry

\begin{tabular}{||c|c||}
\hline \multicolumn{2}{|c|}{ Aircraft LASTA } \\
\hline \hline Wing span & $9.015 \mathrm{~m}$ \\
\hline Wing aspect ratio & 6.3 \\
\hline Fuselage length & $7.97 \mathrm{~m}$ \\
\hline Mean aerodynamic chord & $1.461 \mathrm{~m}$ \\
\hline Wing area & $12.9 \mathrm{~m}^{2}$ \\
\hline Fuselage width & $0.98 \mathrm{~m}$ \\
\hline Propeller diameter & $1.98 \mathrm{~m}$ \\
\hline Mass of airplane & $1160-1250 \mathrm{~kg}$ \\
\hline
\end{tabular}

Correct prediction of the take-off distance is directly correlated with the accurate value of propeller efficiency factor. Predicting the propeller efficiency factor is the hardest

\footnotetext{
1) Military Technical Institute (VTI), Ratka Resanovića 1, 11132 Belgrade, SERBIA

2) Technical Test Centre, Vojvode Stepe 445, 1100 Belgrade, SERBIA

3) Faculty of Mechanical and Civil Engineering in Kraljevo, Dositejeva 19, 36000 Kraljevo, SERBIA

Correspondence to: Miodrag Milenković-Babić; e-mail: miodragmbm@yahoo.co.uk
} 
task during preliminary design phase when the propeller characteristics are not known. This problem will be discussed in more detail in the next section. According to [5], if the propeller efficiency is not known, the following values can be used as expected approximations: fixed pitch climb propeller $\eta_{\text {propeller }}=0.45-0.50$, fixed pitch cruise propeller $\eta_{\text {propeller }}=0.35-0.45$ and constant speed propeller $\eta_{\text {propeller }}=0.45-0.60$.

With the information available at present, it is unfortunately not possible to provide an improved prediction for propeller efficiency factor. This and all other uncertainty will have their effect on the calculated results for take-off and landing distance that will be compared to flight test results. Development of new software tools for the evaluation of aircraft take-off and landing performance is still in focus nowadays [7-9].

The LASTA aircraft was designed according to FAR-23 [2] regulations (aerobatic category) and military standards [10]. The LASTA is a constant speed (RPM) propeller driven aircraft and presents a new generation of primary and basic trainer, developed to provide a high training effectiveness and easy transition to any advanced training airplane. The aircraft was developed by the Military Technical Institute (VTI, Belgrade) and produced by UTVA Aviation Industry in Pančevo. The purpose of LASTA aircraft is to enable: pilot selection, basic training, aerobatic flying, basic weapons training, navigation and night flying.

\section{Take-off distance}

According to the regulations [1], take-off distance is defined as the distance covered from brake release to clearing an obstacle at the height of $15 \mathrm{~m}(50 \mathrm{ft})$ above the runway and must be determined for each weight, altitude and temperature within the operational limits established for take-off. It is assumed that take-off phase consists of ground roll phase and airborne phase. The ground roll distance can be calculated by using the equation (1):

$$
s_{L O}=\frac{V_{L O}{ }^{2} \cdot m}{2 F_{e f f}} .
$$

In equation (1) the lift-off speed and effective force that acts upon the aircraft during take-off phase are given by equation (2):

$$
\begin{aligned}
& V_{L O}=1.1 \cdot V_{s 1} \text { where } V_{s 1}=\sqrt{\frac{2 \cdot \frac{m \cdot g}{S}}{\rho \cdot C_{z_{\max }}}} \\
& \text { and } F_{e f f}=T-\left[F_{X}+\mu_{t r}\left(\mathrm{mg}-F_{Z}\right)\right] .
\end{aligned}
$$

In the above equation the propeller thrust force is given by equation (3):

$$
T=\frac{P}{V} \eta_{\text {propeller }}
$$

The aerodynamic lift and drag forces in equation (2) are obtained from the Military Technical Institute internal report [11]. The report [11] is one of reports that contained wind tunnel results of the LASTA aircraft model. It contained the wind tunnel test data of LASTA aircraft model in variable configuration, range of angle of attack and sideslip angles and different position of controls. The testing results of the LASTA model in the T-35 wind tunnel, at Mach number
$\mathrm{M}=0.1$ are given in [12]. The data from [11] have been used in order to get more precise results of aircraft performance as the design and construction phase of project were in the final stage. For the preliminary calculation these data can be estimated by calculating aerodynamic equations given in [13].

In the design phase of an aircraft, it is necessary to obtain experimental tests in wind tunnel on a model which gives more reliable values of aerodynamic lift, drag and especially moment. The paper [14] presents a method how to do a correction of drag force coefficients for a given model of LASTA aircraft based upon the flight test results. Today, modern approach implies the usage of computational fluid dynamics (CFD) [15-18] in order to get more accurate results than classical calculation methods. Benefit of using CFD methods is that they can simulate some processes that are impossible to do in wind tunnel or analytically and can be applied on a real model size. One example that shows the advantage of CFD and wind tunnel on classical calculation methods is a spin analysis presented in [19]. Comparison of the CFD computational results and wind tunnel experimental results for the LASTA aircraft at high angles of attack are given in [17].

It should be mentioned that the wind tunnel experiments on models, even at subsonic speeds, are liable to three main sources of error when used to forecast full-scale results. These are: scale effects, interference from wind tunnel walls, and errors in model which are all explained in [14]. Some additional information about correlation between flight test and wind tunnel data can be found in [20]. As an example, in a diagram (Fig.2), the lift and drag force coefficients are presented for the LASTA aircraft model in take-off configuration taken from [12].

The contribution of the propeller, on lift and drag force coefficients was not included in the wind tunnel results as non-propeller aircraft model was tested. This effect is expected to have negligible contribution to the lift force coefficient during take-off and landing, and very small contribution to drag force coefficient. Taking into account all these effects, it was decided to increase drag force coefficient by $10 \%$ during calculation of take-off distance in order to include a drag of the propeller and all other tubes, sensors, antennas and installations that exist on the real aircraft and are not included on the aircraft wind tunnel model.

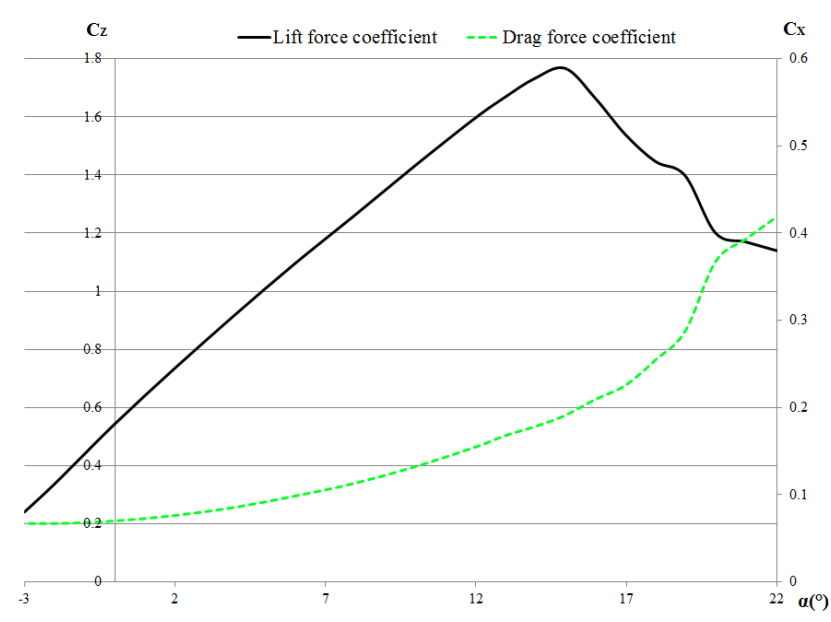

Figure 2. Lift and drag force coefficients versus angle of attack for LASTA aircraft model in take-off configuration

Propeller performance at low Reynolds numbers is very important part in the design and performance prediction phase of aircraft design. In equation (3), the effective engine power is obtained from [21] and the propeller efficiency factor is 
estimated on value $\eta_{\text {propeller }}=0.45$.

When the charts from [21] have been used to estimate the power being delivered to the propeller, some certain reservations and shortcomings should be kept in mind. First, it needs to be determined whether the engine was calibrated. If not, the chart may not be strictly applicable. Second, when the engine is installed in the aircraft, certain losses will occur, and thus the power will not equal the power measured on a dynamometer in the factory. This reduction is called thrust deduction and results from the fact that the drag of a fuselage is increased when a propeller is placed in front of it thus decreasing the effective propeller thrust.

The propeller efficiency is a function of the propeller RPM, propeller diameter and true airspeed. All these parameters are combined into a non-dimensional parameter called the advance ratio given by equations (4):

$$
J=\frac{V}{N D} \text {. }
$$

In equations (4) $V$ is the true airspeed, $N$ is the propeller rotational speed and $D$ is propeller diameter. It also depends on the power coefficient, which is a function of propeller rotational speed and propeller diameter and also the air density as well as the brake horsepower. Specifically, the coefficient of the absorbed power, $C_{p}$, given by equations (5):

$$
C_{p}=\frac{P}{\rho N^{3} D^{5}}
$$

is another non-dimensional parameter, where $P$ is the brake horsepower and $\rho$ is the local air density. More useful information about propeller efficiency can be found in [22].

During the take-off phase the speed increases and the advance ratio of the propeller also increases. In a diagram (Fig.3), there is demonstrated that when the propeller speed increases, the performance improves.

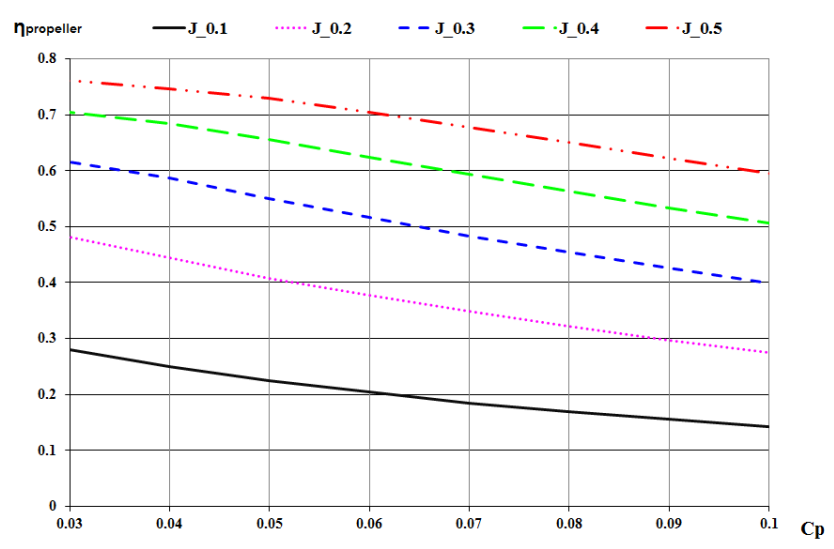

Figure 3. Propeller efficiency

The propeller efficiency presented in a diagram (Fig.3) is a function of the advance ratio and the coefficient of absorbed power. It should be noted that propeller efficiency presented in Figure 3 does not include ground effects. From the take-off phase, the coefficient of absorbed power is estimated to $C_{p}=0.0657$ and, according to the information from Fig.3, the propeller efficiency is in the range from 0.2 to 0.65 .

As it is well known, the static propeller force is the maximum force that propeller has and it suggests that starting acceleration will be maximal. On the diagram (Fig.4), the indicated airspeed is presented as a function of time during take-off phase. After less than 1s the speed of airplane is increased to the value of more than $10 \mathrm{~m} / \mathrm{s}$. In the next part of take-off phase, it is reasonable to assume that airplane speed is linearly increased with time, along two different gradients.

Table 2 presents a functional dependence of the advance ratio versus airspeed. Relevant value for coefficient of absorbed power is also given in Table 2 based on eq. (5). Thus, these results indicated that propeller efficiency of 0.45 is an adequate average value for take-off phase. The reason for low value of propeller efficiency is low value of lift-off speed. For aircraft with constant speed propeller and higher lift-off speed it is reasonable to expect a higher value of propeller efficiency.

Table 2. Advance ratio as a function of aircraft speed

\begin{tabular}{|c||c|c|c|c|c|c||}
\hline$V(\mathrm{~m} / \mathrm{s})$ & 0 & 10 & 20 & 30 & 35 & 40 \\
\hline$V(\mathrm{~km} / \mathrm{h})$ & 0 & 36 & 72 & 108 & 126 & 144 \\
\hline$J$ & 0 & 0.114 & 0.229 & 0.343 & 0.4 & 0.46 \\
\hline$C p$ & \multicolumn{6}{|c|}{0657} \\
\hline
\end{tabular}

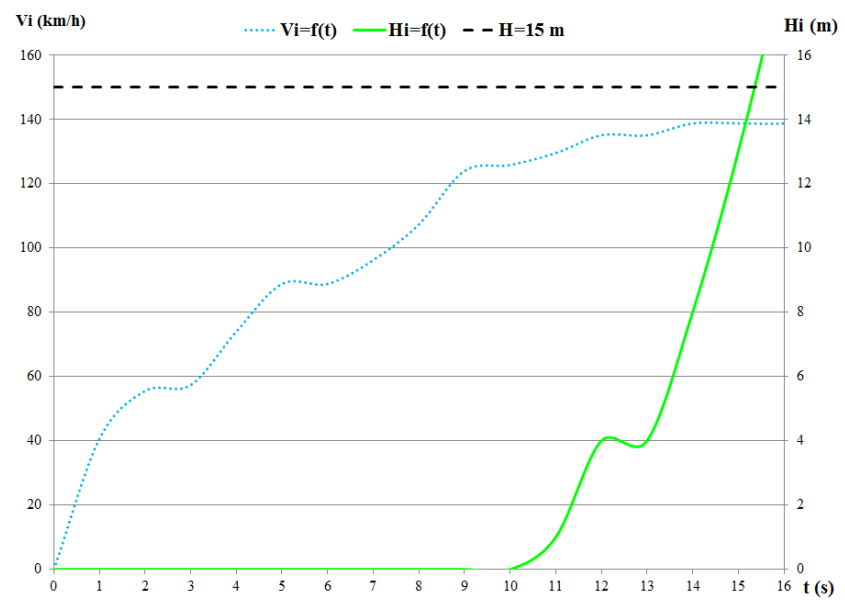

Figure 4. Airplane indicated speed and instrumental altitude during take-off phase

Average forces acting on the airplane during take-off phase is according to [5], force present when speed of airplane is 70 $\% V_{L O}$. Calculated results for thrust force when speed of airplane is $70 \% V_{L O}$ gave unrealistically high results for thrust force considering available results for static propeller force obtained by tests.

The last section discusses on how to solve the take-off distance problem assuming that acceleration remains constant and can be defined at the average speed of $70 \% V_{L O}$. As it is mentioned in [23], this may not be a good assumption for some airplanes if the acceleration varies significantly during the take-off roll. For many airplanes, the take-off acceleration drops off somewhat as $V_{L O}$ is approached. To obtain a more precise prediction of the take-off roll, a numerical integration technique, or a numerical method, should be used. Numerical integration of speed during take-off phase given in Fig. 4 gave the average speed of $102.48 \mathrm{~km} / \mathrm{h}$ or equivalently $86.1 \%$ of $V_{L O}$. This confirmed the assumption that average speed during take-off phase can deviate very much from the recommended value given in [5].

On the other hand, according to the information given in [24], one additional consideration is necessary in the ground run phase. Airflow from the propeller interacts with the ground and there is possibly up to $30 \%$ loss in available thrust close to the ground for most light aircraft. As it is well known and explained in [5], the angle of attack of the blade varies with airspeed and the propeller's thrust will do so as well. It follows that the propeller efficiency is a function of airspeed (advance ratio). These losses in the propeller 
efficiency are probably caused by the low advance ratio as it is mentioned previously and low Reynolds number during take-off phase.

The second phase, while airplane is airborne and needs to clear an obstacle height of $15 \mathrm{~m}$, is calculated by equation (6):

$$
s_{A}=R \sin \theta_{O B} .
$$

In equation (6) the radius of curvature path for the take-off phase and angle $\theta_{O B}$ are given by equations (7):

$$
R=\frac{6.95 \cdot V_{S 1}^{2}}{g} \text { and } \theta_{O B}=\operatorname{arc}(\cos \theta)=1-\frac{15}{R} \text {. }
$$

In the above equation the stalling speed depends on airplane mass, altitude and temperature. The take-off distance is given by equation (8):

$$
s_{T O}=s_{L O}+s_{A}
$$

\section{Landing distance}

The landing distance consists of three parts: approach distance, flare distance and ground roll distance. During landing, the vertical speed needs to be reduced to less than 5 $\mathrm{m} / \mathrm{s}$. At 4 to $5 \mathrm{~m}$ or so above the runway, the pilot fully retards the power lever and raises the noise to fly level, in effect to fly a $0.3 \mathrm{~m}$ or so above the runway with reducing speed. In this attitude, the aircraft touches down with a very small rate of descent just above the stall speed. Approach distance is given by equation (9):

$$
s_{A P}=\frac{15-h_{f}}{\tan \theta_{A P}} .
$$

The approach flight path angle is defined by regulations [1] with the value $\theta_{A P} \leq 3^{\circ}$. For the presented analysis the value of $3^{\circ}$ is used. Airplane altitude above the runway at the end of the approach phase is presented in equation (10):

$$
h_{f}=R\left(1-\sin \theta_{A P}\right) \text {. }
$$

In equation (10) the radius of curvature is given by equation (11):

$$
R=\frac{\left(V_{A P}\right)_{s r}^{2}}{g(n-1)} .
$$

In equation (11) the average value for load factor is defined as $n=1.2$ based upon experience and average approach speed is given by equation (12):

$$
\left(V_{A P}\right)_{s r}=k \cdot V_{s 1}, k=1.23 .
$$

The flare distance is given by equation (13):

$$
s_{\text {FLARE }}=R \sin \theta_{A P} .
$$

The ground roll distance during landing phase is given by equation (14):

$$
s_{G R}=-\frac{V_{T D}^{2} \cdot m}{2 F_{e f f}} \text { where } V_{T D}=1.15 \cdot V_{S 0} .
$$

The stalling speed in landing configuration is obtained by equation (15):

$$
V_{s 0}=\sqrt{\frac{2 \cdot \frac{m \cdot g}{S}}{\rho \cdot C_{z_{\max }}}} .
$$

In the equation (14) the effective force that is acting upon the airplane during landing phase is given by equation (16):

$$
F_{e f f}=-\left[F_{X}+\mu_{t r}\left(\mathrm{mg}-F_{Z}\right)\right] .
$$

Finally, landing distance is given by equation (17):

$$
s_{L A N D}=s_{A P}+s_{F L A R E}+s_{G R} .
$$

The equations presented in this paper have been used because they can give quick and reliable results. The second contribution of presented method is that it can be used to establish altitude effects from the sea level to $3048 \mathrm{~m}$ as it is required by the paragraph 23.1587 in EASA CS-23 regulations. The paragraph just mentioned requires that the temperature influence from standard temperature to $30^{\circ} \mathrm{C}$ above the standard can be demonstrated. The Earth's atmosphere changes with altitude, regionally around the globe, and with the weather also. Despite these variations, performance is nearly always calculated against a standard atmosphere model in which the properties vary only with altitude. Several such models can be applied and the nonstandard atmosphere conditional can be found in [25-26].

\section{Flight testing}

The flight test procedure for take-off and landing distance has the same description in all of regulations [1-2] and will not be discussed in this paper. Useful information about flight testing can be found in [27-29]. The method used to obtain take-off and landing distance is movie theodolite method which is well summarized in [27] and Global Position System device Leica GPS1200 [30]. Additional information about flight test equipment used during testing of LASTA aircraft can be found in [31]. According to [1], the primary objective of the take-off requirement is to provide information about take-off distance to the operator. The take-off distance is a distance within which airplane may be expected to achieve a speed and height sufficient to ensure the capability of performing all maneuvers that may become necessary for the safe completion of take-off, and for the safe landing induced by a power failure. An airspeed margin above stall in conjunction with a height of $15 \mathrm{~m}$ (50 feet) is presumed to assure the desired maneuvering capability. The same is valid for landing phase with additional requirements based upon the lateral maneuver condition given in [32-34].

The flight test investigation has been done in the Technical Test Center [35]. The Technical Test Center is a certified organization for testing of civil aircraft based on the certificate issued by the Civil Aviation Directorate of Serbia. During the last sixty years, a hundred aircraft have been tested in the Technical Test Center. The Technical Test Center is responsible for testing of military airplanes and helicopters for the Serbian Ministry of Defense.

\section{Results of the analysis and discussion}

According to the method presented above, in Table 3, the results for take-off and landing distance necessary for safe completion of take-off and landing are presented.

Those results have been calculated for standard atmospheric conditions and dry concrete/asphalt runway. 
Flight test results from [36], for LASTA prototype 2 aircraft are given in Table 4. For the reduction of take-off and landing measurements to standard conditions a reference [37] should be used.

Table 3. Take-off and landing distances

\begin{tabular}{||c|c|c|c|c||}
\hline \multirow{2}{*}{$H(\mathrm{~m})$} & \multicolumn{2}{|c|}{$m=1160 \mathrm{~kg}$} & \multicolumn{2}{c||}{$m=1250 \mathrm{~kg}$} \\
\cline { 2 - 5 } & $s_{T O}(\mathrm{~m})$ & $s_{\text {LAND }}(\mathrm{m})$ & $s_{T O}(\mathrm{~m})$ & $s_{\text {LAND }}(\mathrm{m})$ \\
\hline \hline 0 & 305 & 505 & 355 & 525 \\
\hline 1000 & 360 & 528 & 425 & 550 \\
\hline 2000 & 445 & 553 & 535 & 575 \\
\hline 3000 & 565 & 582 & 690 & 610 \\
\hline
\end{tabular}

Table 4. Take-off and landing distances from flight tests

\begin{tabular}{|c|c|c||}
\hline \multirow{2}{*}{$H(\mathrm{~m})$} & \multicolumn{2}{|c|}{$m=1160 \mathrm{~kg}$} \\
\cline { 2 - 3 } & $s_{T O}(\mathrm{~m})$ & $s_{\text {LAND }}(\mathrm{m})$ \\
\hline 0 & 328 & 451 \\
\hline
\end{tabular}

In the diagram (Fig.5), three different landing distances obtained by flight test are presented. Experimental flight test results presented in Table 4 are obtained by averaging mean values from several flights. This result has been accomplished by the test-pilots. The obtained results from the flight tests and calculated results are in a good agreement. The difference of about $10 \%$ is excellent for preliminary calculation. The difference is probably a consequence of inability of the method to obtain the exact average force value that acts on the aircraft during this manoeuvre. Underestimation of take-off length is a consequence of optimistic estimation of the average forces that acton the airplane during take-off phase. As it is mentioned in [5], the average force calculated at speed of $70 \%$ of lift-off speed can be too optimistic for light aircraft. If the take-off distance is calculated again with the average speed of $85 \%$ of lift-off speed the obtained take-off distance is $364 \mathrm{~m}$. This result deviates from the flight test results for $10 \%$, but it defined longer runway distance and increased the safety of flight.

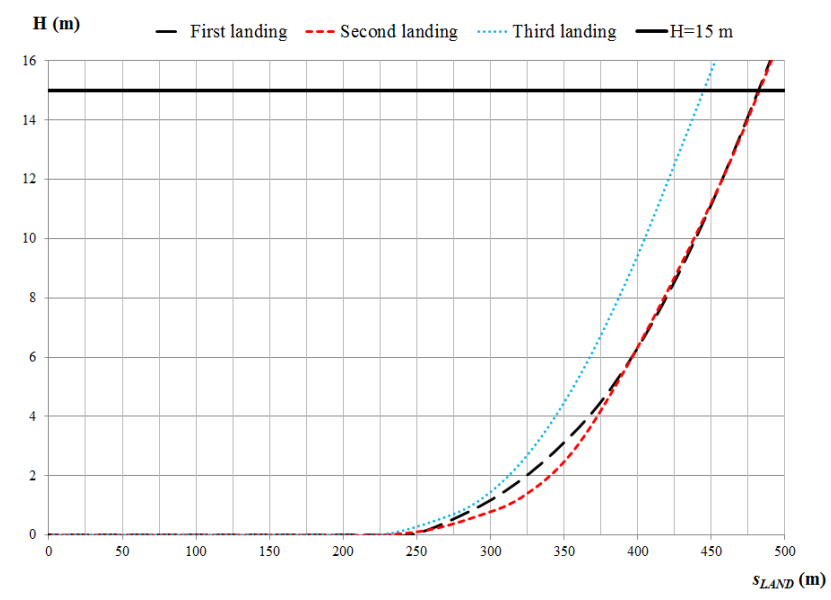

Figure 5. Airplane landing distance

Inthe diagram (Fig.4), the airplane indicated speed and instrumental altitude during the take-off phase are presented accomplished by a pilot of average skills. When the pilot released brakes the airplane started to accelerate and take-off phase has been initiated. According to Fig.4, the starting altitude is $0 \mathrm{~m}$ and take-off phase is finished when the airplane is $15 \mathrm{~m}$ above the runway.

The measured data for take-off, presented in Fig.4, provide data for determination of the function $V_{i}=f(t)$. The numerical integration of this function $V_{i}=f(t)$ during time period from the point where $V_{i}=0 \mathrm{~km} / \mathrm{h}$ (airplane in rest), to the point where the airplane is $15 \mathrm{~m}$ above the ground gives a take-off distance. In the airborne phase it is necessary to include the flight path angle in calculation process to get more accurate results. According to the presented diagram (Fig.4), the calculated take-off distance is $s_{T O}=410 \mathrm{~m}$. The reason for such longer take-off distance in this example is higher lift-off speed $\left(V_{L O}=125.9 \mathrm{~km} / \mathrm{h}\right)$ that is presented in the diagram (Fig.4). It was almost $7 \mathrm{~km} / \mathrm{h}$ higher than the recommended lift-off speed $V_{L O}=119 \mathrm{~km} / \mathrm{h}$ taken from [38]. Analyzing this fact, the calculated distance during this additional time that airplane has spent on runway is $50 \mathrm{~m}$.

The example above shows that the mean take-off distance obtained by the test-pilots is not representative take-off distance that will be obtained by the pilots of average skills. According to [39], the accidents like failure to get airborne, collision with obstacles after take-off and overrun on landing occurs frequently to light airplanes. In addition, it is noticeable that many of these accidents could have been avoided if the pilots had been fully aware of the airplane performance limitations. The purpose of just mentioned documents is to extend the awareness of the action that needs to be taken to ensure that airplane take-off, climb and landing performance are adequate. Influence of the factors such as: airplane weight, slope of ground, temperature, wind, rain drops, mud, insects, ice, engine failure, flaps setting, humidity and so forth on runway length necessary for take-off and landing is also given in [39], where they recommend that safety factor should be used to establish take-off and landing distance needed for the safe flight. Those factors were taken from [40]. By using these factors take-off and landing distances presented in Table 3 should be multiplied by 1.33 and 1.43 respectively in order to get the minimum required runway distance for a safe flight. These data are given in Table 5 and represent minimum take-off and landing distances for the safe flight in the standard atmosphere on a dry concrete/asphalt. If there is any doubt about take-off and landing distance the pilot should consider information given in the Airplane Flight Manual and [39-40]. These documents should provide needed information for safe flight.

Table 5. Minimum take-off and landing distances for safe flight corrected with safety factor

\begin{tabular}{|c|c|c|c|c||}
\hline \multirow{2}{*}{$H(\mathrm{~m})$} & \multicolumn{2}{|c|}{$m=1160 \mathrm{~kg}$} & \multicolumn{2}{c||}{$m=1250 \mathrm{~kg}$} \\
\cline { 2 - 5 } & $s_{T O}(\mathrm{~m})$ & $s_{L A N D}(\mathrm{~m})$ & $s_{T O}(\mathrm{~m})$ & $s_{L A N D}(\mathrm{~m})$ \\
\hline \hline 0 & 405 & 725 & 475 & 750 \\
\hline 1000 & 480 & 755 & 565 & 785 \\
\hline 2000 & 595 & 795 & 710 & 825 \\
\hline 3000 & 750 & 835 & 915 & 870 \\
\hline
\end{tabular}

\section{Conclusion}

Methodology for determination of take-off and landing performances of the single engine tractor propeller aircraft has been presented in this paper to offer a rapid estimation of take-off and landing distance needed for a safe flight.

The comparison between flight test data and calculated results is in a very good agreement. For the presented aircraft average thrust force acting on the aircraft is force that existed when the speed of aircraft is $86.1 \%$ of $V_{L O}$ for pilot of average skills and it deviated from recommended speed $0.7 V_{L O}$ from literature. This strongly suggests that, in order to increase flight safety, it is necessary to usea more conservative approach or to use safety factors from [39-40] and to compensate any irregular pilot techniques, weather conditions or any other factor that will increase the necessary runway distance. 
The results of this analysis show that it is still impossible to accurately predict take-off and landing performance of the piloted aircraft due to the pilot diversity, insufficiently accurate determined parameters as is propeller efficiency factor and that it is mandatory to use safety factors to assure the safe flight.

The presented paper should increase awareness of possible accidents during take-off and landing phase of flight and give some terms of reference to reduce it.

\section{Acknowledgments}

The authors express sincere gratitude to the colleagues from the Military Technical Institute (VTI), Belgrade, and the Technical Test Centre, Belgrade, for their assistance, help at each stage of the work process and support.

\section{References}

[1] EASA CS-23. Certification specifications for normal, utility, aerobatic and commuter category aeroplanes, 2014.

[2] Federal Aviation Regulation Part 23-Airworthiness Standards: Normal, Utility, Acrobatic, and Commuter Category Airplanes, 2002.

[3] PERKINS,C.D., HAGE,R.E.: Airplane performance stability and control, John Wiley\& Sons, New York, 1949.

[4] CHENG,H., GRANDHI,R.V., HANKEY,W.L., BELCHER,P.J.: Take off and Landing Analysis Methodology for an Airbreathing Space Booster, Acta Astronautica 1993, Vol.29, No.5, pp.325-332.

[5] SNORRI,G.: General Aviation Aircraft Design: Applied Methods and Procedures, Elsevier Inc, 2014.

[6] Vojnotehnički Institut Vojske Srbije 1948-2018, Monografija VTI, Beograd, 2018.

[7] OHME,P.: A Model-Based Approach to Aircraft Takeoff and Landing Performance Assessment, AIAA Atmospheric Flight Mechanics Conference, 2009, 10 - 13 August.

[8] VELIMIROVIĆ,K., VELIMIROVIĆ,N.: LASTA aircraft with turboprop engine - Determination flight performances, Program "Turbolastaperf", 6th International Scientific Conference on Defensive Technologies, OTEH 2014, 09-10. October, Military Technical Institute, Belgrade, SERBIA,, pp.192-197.

[9] FILIPPONE,A.: Comprehensive analysis of transport aircraft flight performance, Progress in Aerospace Science 44, 2008, pp.192-236.

[10] MIL-F-8785C. Military Specification-Flying qualities of Piloted Airplanes, 1980.

[11] B3-2870-I-EA, Ispitivanje modela aviona LASTA-95, R1:5, u aerotunelu T-35, VTI, Beograd, 2005.

[12] OCOKOLJIĆ,G., ANASTASIJEVIĆ,Z.: Determination of Aerodynamic Coefficients and Visualization of the Flow Around The LASTA-95 Aircraft Model Part I: Experimental Method, Scientific Technical Review, ISSN 1820-0206, Vol 58, No.1, 2008.

[13] USAF stability and control DATCOM, McDonnell Douglas Corporation, Douglas Aircraft Division, 1978.

[14] BAJOVIĆ,M., MOLOVIĆ,V.: Wind-tunel/flight correlation drag polars of light airplanes, $4^{\text {th }}$ International Scientific Conference on Defensive Technologies, OTEH 2011, 06-07. October, Military Technical Institute, Belgrade, SERBIA, pp.39-42.

[15] Raymer,D.: Aircraft Design: A Conceptual Approach, Fifth edition, AIAA education series, 2012

[16] DEAN,J., CLIFTON,J., BODKIN,D. MORTON,S., MCDANIEL,D.: Determining the Applicability and Effectiveness of Current CFD Methods in Store Certification Activities, 48th AIAA Aerospace Sciences Meeting Including the New Horizons Forum and Aerospace Exposition, 4 - 7 January 2010, Orlando, Florida.
[17] KOZIĆ,M.: Comparison of the Navier-Stokes computations with the experiment for LASTA-95 wing at high angles of attack, Scientific Technical Review, ISSN 1820-0206, 2006, Vol.56, No.1, pp.41-44.

[18] DOVATOV,B.: Primena numeričke dinamike fluida za određivanje uticaja modifikacije zadnjeg dela trupa avona $G-4,3^{\text {th }}$ International Scientific Conference on Defensive Technologies, OTEH 2009, 08-09. October, Military Technical Institute, Belgrade, SERBIA.

[19] KOZIĆ,M.: Navier-Stokes Computations and Experimental Comparisonsfor Rudder EfficiencyAnalysis in the Moderately Steep Spin Part II: Computation Method, Scientific Technical Review, ISSN 1820-0206, 2018, Vol.68. No.1, pp.61-65.

[20] BAJOVIĆ,M., VELIMIROVIĆ,K., MOLOVIĆ,V., VELIMIROVIĆ,N.: The analysis of aerodiynamical coefficient grounded on wind tunnel and flight tests, $3^{\text {th }}$ International Scientific Conference on Defensive Technologies, OTEH 2009, 08-09. October, Military Technical Institute, Belgrade, SERBIA

[21] Lycoming aircraft engine performance data (See level and altitude performance curve-IO-540-K).

[22] ROGERS,D.F.: Propeller Efficiency Rule of Thumb, American Bonanza Society, 2010.

[23] Yechout, T.: Introduction to Aircraft Flight Mechanics. AIAA Education Series, 2003.

[24] ALLERTON,D.: Principles of Flight Simulations, John Wiley\& Sons, 2009.

[25] MIL-HDBK-310. Global climatic data for developing military products, June, 1997.

[26] MIL-STD-3013A, Glossary of definitions, ground rules, and mission profiles to define air vehicle performance capability, Department of Defense standard practice, September, 2008.

[27] KIMBERLIN,R.: Flight Testing of Fixed-wing Aircraft, American Institute of Aeronautics and Astronautics, Virginia, 2003.

[28] CIVIL AVIATION AUTHORITY OF NEW ZELAND, Take off and Landing Performance, January, 2011.

[29] PHAK-Chapter 10, Pilots Handbook of Aeronautical Knowledge, October, 2008.

[30] http://www.leica-geosystems.com/downloads, Data of last access: 04/28/2018.

[31] PEKMEZOVIĆ,S., JOVANOVIĆ,M., ILIĆ,Z.: Flight testing methodology and procedure of spin characteristic on basic training aircraft, $4^{\text {th }}$ International Scientific Conference on Defensive Technologies, OTEH 2011, 06-07. October, Military Technical Institute, Belgrade, SERBIA, pp.128-132.

[32] STOJAKOVIĆ,P., RAŠUO,B.: Single propeller airplane minimal flight speed based upon the lateral maneuver condition, Aerospace Science and Technology. 49 (2016), pp.239-249.

[33] STOJAKOVIĆ,P., RAŠUO,B.: Minimal safe speed of the asymmetrically loaded combat airplane, Aircraft Engineering and Aerospace Technology, 2016, Vol.88, No.1, pp.42 - 52 .

[34] STOJAKOVIĆ,P., VELIMIROVIĆ,K., RAŠUO,B.: Power optimization of a single propeller airplane take-off run on the basis of lateral maneuver limitations, Aerospace Science and Technology, 72 (2018), pp.553-563.

[35] http://www.toc.vs.rs/Data of last access: 04/28/2018.

[36] B3-0577-P-06, Avion LASTA potrebna dužina poletno-sletne staze, VTI, Beograd, 2015.

[37] ESDU, Reduction of take-off and landing measurements to standard conditions, ESDU Item No. RG 2/1, July 1962 (with Amendments A, April 1987).

[38] Flight Manual of the LASTA aircraft, (in Serbian).

[39] Civil Aviation Authority, Safety sense leaflet $7 C$ aeroplane performance, January, 2013.

[40] AIC 127/2006. United Kingdom aeronautical information circular, take-off, climb and landing performance of light aeroplanes.

Received:12.03.2019. Accepted:25.04.2019. 


\section{Avion Lasta: dužina poletno-sletne staze}

U ovom radu prikazana je analiza potrebne dužine poletno-sletne staze jednomotornog aviona LASTA pogonjenog vučnom elisom. Svrha ove analize je da omogući sertifikaciju aviona LASTA po civilnim vazduhoplovnim propisima CS-23. U ovom radu prikazana je aproksimativna metoda za proračun potrebne dužine poletno-sletne staze i upoređena je sa rezultatima letnih ispitivanja. Postignuto je dobro slaganje proračunskih i eksprimentalnih rezultata.

Ključne reči: dužina poletno-sletne staze, jednomotorni avion, letna ispitivanja. 